\title{
Korelasi Kandungan Logam Berat Pb dalam Air terhadap Daun Lamun Thalassia hemprichii (Ehrenberg) Ascherson 1871 (Magnoliopsida: Hydrocharitaceae) di Perairan Pulau Panjang dan Pantai Bandengan, Jepara
}

\author{
Dara Ramadhania Istiqomahani*, Chrisna Adhi Suryono, Rini Pramesti \\ Departemen IImu Kelautan, Fakultas Perikanan dan IImu Kelautan, Universitas Diponegoro \\ JI. Prof. H. Soedarto S.H, Tembalang, Semarang, Jawa Tengah 50275 Indonesia \\ ${ }^{*}$ Corresponding author, e-mail : daramadhania@gmail.com
}

\begin{abstract}
ABSTRAK: Kegiatan manusia meliputi pertanian, industri, mebel, pariwisata dan kegiatan nelayan di Pulau Panjang dan Pantai Bandengan diduga menjadi sumber logam berat $\mathrm{Pb}$. Tujuan penelitian ini adalah mengetahui nilai konsentrasi dan hubungan kandungan logam berat $\mathrm{Pb}$ pada Air dan daun lamun Thalassia hemprichii di Pulau Panjang dan Pantai Bandengan, Jepara Materi yang digunakan dalam penelitian ini adalah sampel air kedua perairan dan daun lamun $T$. hemprichi. Hasil penelitian menunjukan. Konsentrasi $\mathrm{Pb}$ dalam air laut yang ada di kedua daerah tersebut rata rata antara 0,034-0,054 ppm sedangkan dalam daun lamun 0,509-1,334 ppm. Korelasi antara konsentrasi logam berat $\mathrm{Pb}$ dalam air dan daun lamun $T$. hemprichii menunjukan tingginya keeratan hubungan atara dua faktor tersebut. Bila konsentrasi $\mathrm{Pb}$ dalam air laut meningkat akan diikuti dengan peningkatan konsentrasi $\mathrm{Pb}$ dalam daun lamun dengan sangat nyata.
\end{abstract}

Kata Kunci : Logam berat; $\mathrm{Pb}$; air laut; daun lamun; korelasi

\section{The Correlation Between Heavy Metal Pb in Marine Waters and Seagrass Leaves of Thalassia hemprichii (Ehrenberg) Ascherson 1871 (Magnoliopsida:Hydrocharitaceae) at Panjang Island and Bandengan Coastal Waters, Jepara}

\begin{abstract}
Human activities include agriculture, industry, tourism and fishing activities in Panjang Island an Bandengan shores of the supposedly heavy metal Pb (lead). The purpose of this researches to compare the heavy metal content of $\mathrm{Pb}$ (lead) in water and leaves Thalassia hemprichii in Panjang Island an Bandengan shore, based on existing quality. The material used in this researched were the samples of leaves of $T$. hemprichii and water of both. The result showed that the concentration of $\mathrm{Pb}$ in marine waters on two regions between 0,034-0,054 ppm and concentration in seagrass leaves between 0,509-1,334 ppm. The result of the correlation between the concentration of heavy metals $\mathrm{Pb}$ in water and leaves of seagrass showed a high close relationship between the two factors. If the $\mathrm{Pb}$ concentration in seawater rises, it will be followed by an increase in $\mathrm{Pb}$ concentration in leaves of seagrass very significantly.
\end{abstract}

Keywords : Heavy metal; Pb; marine waters; seagrass leaves; concentration

\section{PENDAHULUAN}

Pantai di Jepara banyak yang memliki potensi untuk pariwisata, penangkapan ikan, pelabubah ikan, pertambakan, dan pemukiman. Pantai yang sudah dimanfaatkan untuk kepentingan tersebut seperti Pantai Bandengan dan Pulau Panjang. Namun dikedua pantai tersebut merupakan juga habitat lamun yang baik. Adanya beberapa aktivitas di daerah lamun diduga juga akan menimbulkan dampak terhadap lamun terutama limbah yang mengandun $\mathrm{Pb}$ seperti minyak. Kegiatan pelayaran, pelabuhan, pertambakan (tradisional dan intensif) dan rumah tangga diduga merupakan sumber dari $\mathrm{Pb}$ yang ada di perairan tersebut. Kondisi tersebut akan menyebabkan terjadinya ancaman pencemaran di sekitar perairan (Riza et al., 2015). Pulau Panjang merupakan daerah yang didominasi aktivitas pariwisata. Sebagai lokasi wisata Pulau 
Panjang memiliki dermaga untuk lalulintas kapal wisata (Indarjo, 2015). Pulau Panjang berbeda dengan Pantai Bandengan yang memiliki berbagai aktivitas seperti pemukiman. Wilayah Pantai Bandengan Kabupaten Jepara merupakan daerah padat pemukiman penduduk dengan berbagai aktivitasnya. Kepadatan penduduk ini menyumbang suplai materi organik dan nonorganik pada perairan sekitar (Sulardiono et al., 2016).

$\mathrm{Pb}$ (Timbal) merupakan logam berat yang beracun dan dapat membahayakan kelangsungan hidup lamun di perairan. Efek pemaparan logam $\mathrm{Pb}$ pada tumbuhan lamun dinyatakan dapat menghambat pertumbuhan (Rappe et al., 2011). Dampak kegiatan oleh aktivitas manusia di daratan menyebabkan meningkatnya bahan pencemar yang masuk ke Perairan (Riniatsih et al., 2013). Lamun merupakan tumbuhan yang dapat menyerap logam berat dan salah satunya adalah $\mathrm{Pb}$ (Timbal). Jenis lamun yang terdapat di perairan Pulau Panjang ditemukan 4 spesies lamun sedangkan di Pantai Bandengan hanya ditemukan 2 spesies lamun. Thalassia hemprichiidan Enhalus acoroides dapat ditemukan di kedua lokasi penelitian sedangkan Cymodoceasp dan Syringodiumsp hanya ditemukan di Pulau Panjang (Hartati et al., 2017). Presentase kerapatan lamun pada perairan Pulau Panjang di dominasi jenis lamun Thalassia hemprichiidan Enhalus acoroides (Purwanti et al., 2014). Akumulasi logam berat Zn pada lamun di perairan Kartini Jepara menunjukan bahwa kandungan logam berat di akar lebih tinggi daripada kandungan sedimen, hal ini diduga lamun memiliki sifat hiper kumulator (Putra et al.,2019). menyatakan sejumlah famili tumbuhan dapat dimiliki sifat hiperkumulator atau hipertoleran dimana mampu mengakumulasi logam berat dengan konsentrasi tinggi pada jaringan akar (Nursanti et al., 2013). Lebih lanjut (Supriyantini et al., 2016) mengungkapkan bahwa pencemaran logam berat terakumalasi tertinggi pada akar dan daun lamun. Lingby \& Brix (1982) menyatakan bahwa umur daun lamun mempengaruhi jumlah kadar logam beratnya. Kadar logam berat meingkat sesuai dengan meningkatnya umur lamun tersebut.

Penelitian ini bertujuan untuk mengetahui dan membandingkan kandunganlogam berat $\mathrm{Pb}$ (Timbal) pada Air dan daun lamun T. hemprichii di Pulau Panjang dan Pantai Bandengan, Jepara Jawa Tengah.

\section{MATERI DAN METODE}

Lokasi penelitian ini dilakukan di wilayah perairan pantai Pulau Panjang dan Pantai Bandengan, yang merupakan habitat lamun. Kondisi kedua daerah tersebut sangat mendukungu ntuk pertumbuhan lamun Thalassia hemprichii. Substrat dasar perairan kedua lokasi berbeda dimana Pulau Panjang sebagian besar berupa substrat pasir dan pecahan karang sedangkan Pantai Bandengan berupa pasir berlumpur.
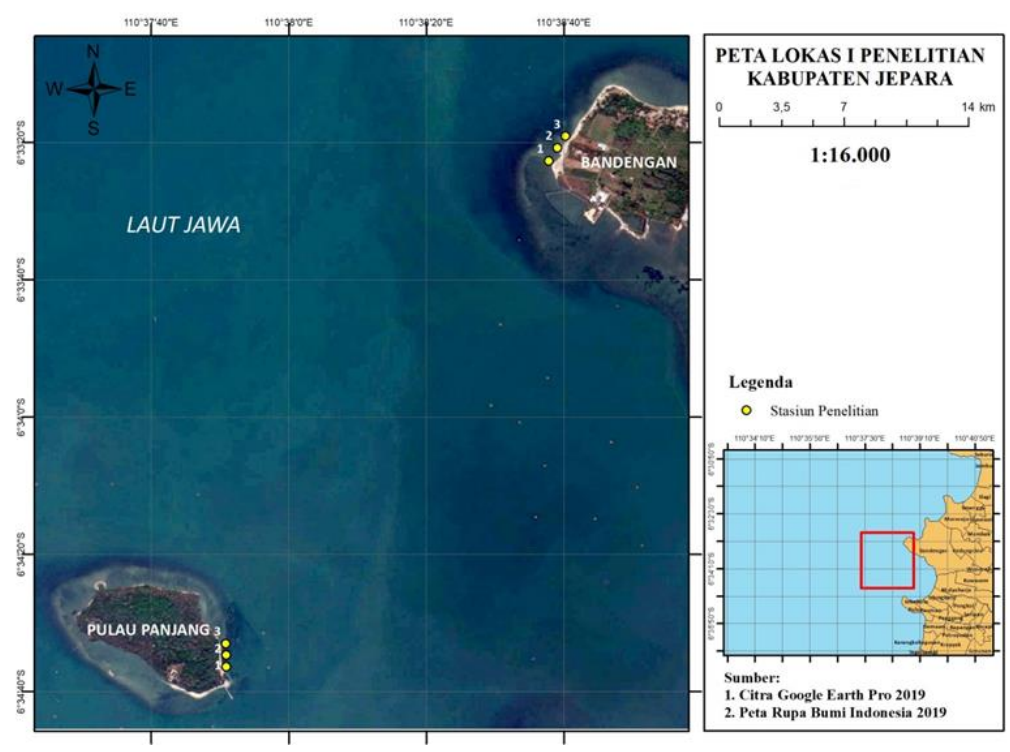

Gambar 1. Lokasi Penelitian Pulau Panjang dan Pantai Bandengan Jepara 
Sampel air laut diabil pada permukaan dengan menggunakan botol sampel $600 \mathrm{ml}$, sedangkan pengabilan sample lamun dengan cara dicabut hingga ke keakar-akarnya sebanyak 3 tegakan pada setiap stasiun. Sampel lamun yang terambil dipisahkan antara bagaian helaidaun, rimpang dan akaruntuk Analisa logamberat (Supriyantini et al., 2016; Putra et al., 2019 )

Sampel lamun yang telah diambil kemudian di destruksi guna memudahkan uji logam berat $\mathrm{Pb}$. Lamun dikeringkan selama beberapa hari untuk mengurangi kadar airnya, kemudian daun lamun dipotong kecil-kecil dan dihaluskan, kemudian dihaluskan hingga menjadi bubuk. Setelah itu sample lamun dikeringkan dalam oven $105^{\circ} \mathrm{C}$ selama 2-3 jam untuk menghilangkan kadar airnya dan diperoleh berat konstan (Sari et al., 2017).

Sampel daun lamun ditimbang sebanyak $\pm 5 \mathrm{gr}$ kemudian dimasukkan kedalam tanur pada suhu $600-650{ }^{\circ} \mathrm{C}$ (pengabuan) selama 3-4 jam. Setelah proses pengabuan selesai selanjutnya sample tersebut dilarutkan dengan menambahkan $20 \mathrm{~mL} \mathrm{HNO}$ pekat dan $10 \mathrm{~mL} \mathrm{HClO}_{4}$. Kemudian ditambahkan aquades sampai volume menjadi $50 \mathrm{~mL}$. larutan tersebut dipanaskan menggunakan hot plate sampai mendidih dan volume berkurang $30 \mathrm{~mL}$. Jika belum terjadi kabut (asap putih) ulangi penambahan $\mathrm{HNO}_{3}$ sebanyak $20 \mathrm{~mL}$ dan $\mathrm{HClO}_{4}$ sebanyak $10 \mathrm{~mL}$ pada larutan tersebut, kemudian dipanaskan kembali hingga terjadi kabut (asap putih) dan larutan sample menjadi jernih (Sugiyanto et al., 2016).

Setelah terjadi kabut (asap putih) kemudian ditambahkan kembali larutan aquades sehingga volume sample menjadi $50 \mathrm{~mL}$, lalularutan sample didinginkan dan diendapkan. Larutan yang telah didinginkan dan diendapkan disaring fasa airnya menggunakan kertas saring. Kemudian filtrate sample dimasukkan kedalam labu ukur $100 \mathrm{~mL}$ dan ditambahkan aquades sampai tepat tanda batas. Larutan sampel yang diperoleh siap dianalisis menggunakan alat AAS (Atomic Absorption Spetrophotometric) (Sari et al., 2017).

Sampel air laut dimasukkan kedalam Erlenmeyer sebanyak $100 \mathrm{~mL}$, kemudian ditambahlan $10 \mathrm{~mL} \mathrm{HNO}_{3}$ pekat. Larutan sample dipanaskan perlahan-lahan menggunkan hot plate sampai volume berkurang $30 \mathrm{~mL}$. Kemudian ditambahkan kembali larutan aquades sampai volume menjadi $100 \mathrm{~mL}$, setelah itu larutan didinginkan dan diendapkan. Proses ini dilakukan secara berulang ingá logam larut, yang terlihat dari warna endapan contoh uji menjadi agak putih atu jernih. Kemudian filtrate sample dimasukkan kedalam labu ukur $100 \mathrm{~mL}$ dan ditambahkan aquades sampai tepat tanda batas. Larutan sampel yang diperoleh siapdianalisis menggunakan alat AAS (Atomic Absorption Spetrophotometric) tipe ICE 3000 (Sari et al., 2017)

\section{HASIL DAN PEMBAHASAN}

Hasil analisa logm $\mathrm{Pb}$ yang terdsapat dalam air laut dan daun lamun terlihat dalam Gambar 2. Hasil analisa logan $\mathrm{Pb}$ dalam daun lamun di kedua lokasi antara Pulau Panjang dan pantai Badengan tidak menunjukan adanya perbedaan di kedua lokasi tersebut $(p=0.997 \geq 0.5)$ demikian juga antara $\mathrm{Pb}$ dalam air di kedua daerah tersebut tidak menunjukan adanya perbedaan $(\mathrm{p}=$ $0.618 \geq 0.5$ ). Hal tersebut menunjukan bahwa antara perairan Pulau Panjang dan Bangengan tidak ada perbedaan konsentrasi $\mathrm{Pb}$ baik dalam daun lamun maupun dalam air laut. Bila dilihat dari baku mutu air laut untuk kehidupan organisme laut konsentrasi yang ada di kedua daerah sersebut rata rata antara $0,034-0,054 \mathrm{ppm}$. Nilai tersebut menunjukkan nilai yang lebih besar dari baku mutu air laut untuk biota laut $(0,008 \mathrm{ppm})$ di kedua daerah. Maka dari itu, kandungan logam berat timbal $(\mathrm{Pb})$ tersebut di air ini melebihi standar baku mutu (Kep.Men.LH.No. 51 Tahun 2004).

Konsentrasi logam berat $\mathrm{Pb}$ yang sudah melewati baku mutu air laut untuk biota laut ini menunjukkan bahwa perairan Pulau Panjang dan Pantai Bandengan ini sudah tercemar berat Pb. Hal ini sangat mengkhawatirkan karena selain perairan tersebut tidak sesuai lagi bagi kehidupan biota laut untuk dapat tumbuh dan berkembang dengan baik, logam berat yang terkandung di dalam perairan dapat terakumulasi pada biota laut tersebut, diantaranya pada tanaman lamun.

Hasil korelasi antara konsentrasi logam berat $\mathrm{Pb}$ dalam air dan daun lamun $T$. hemprichii dapat dilihat dalam Gambar 3, 4 dan 5. Korelasi antara logam berat dalam air laut dan daun lamun di perairan Pulau Panjang menunjukan $(r=0,91)$ yang menunjukan hubungan sangat erat (Gambar 3). Demikian juga pada korelasi antara $\mathrm{Pb}$ air laut dengan daun lamun di Pantai Bandengan $(r=0,89)$ lihat Gambat 4 . Hal yang sama bila data logam dalam air dan daun di kedua daerah tersebut digabungkan menunjukan nilai $(r=0,85)$ lihat Gambar 5. Dari ketiga hubungan 
korelasi tersebut yang ketiganya menunjukan nilai $(r \leq 0,6)$ tingginya keeratan hubungan atara dua faktor tersebut. Bila konsentrasi $\mathrm{Pb}$ dalam air laut meningkat akan diikuti dengan peningkatan konsentrasi $\mathrm{Pb}$ dalam daun lamun dengan sangat nyata.

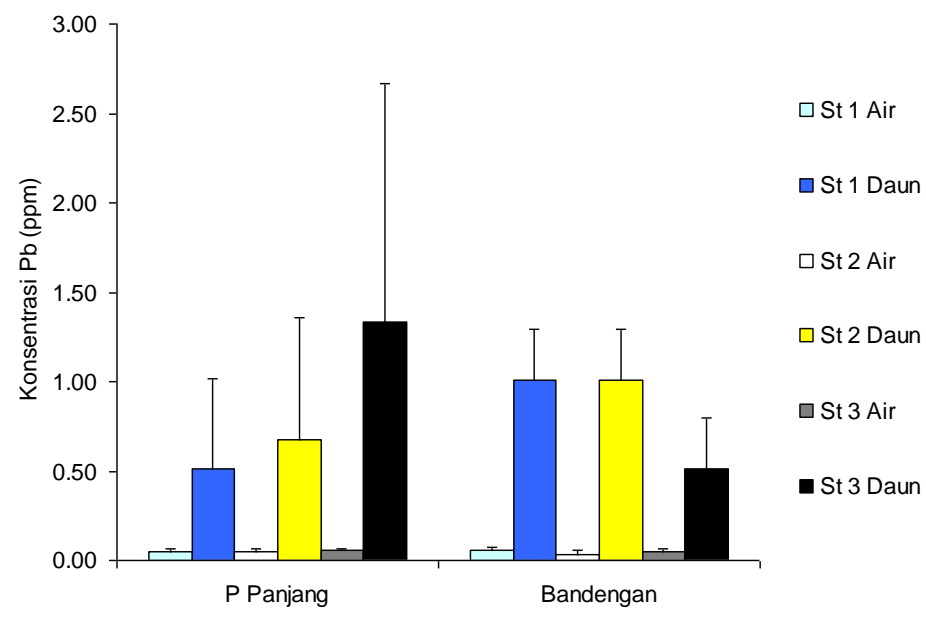

Gambar 2. Rata rata konsentarsi $\mathrm{Pb}$ (ppm) pada air dan daun lamun $T$. hemprichii $+\mathrm{SD}$ di perairan Pulau Panjang dan Bandengan Jepara

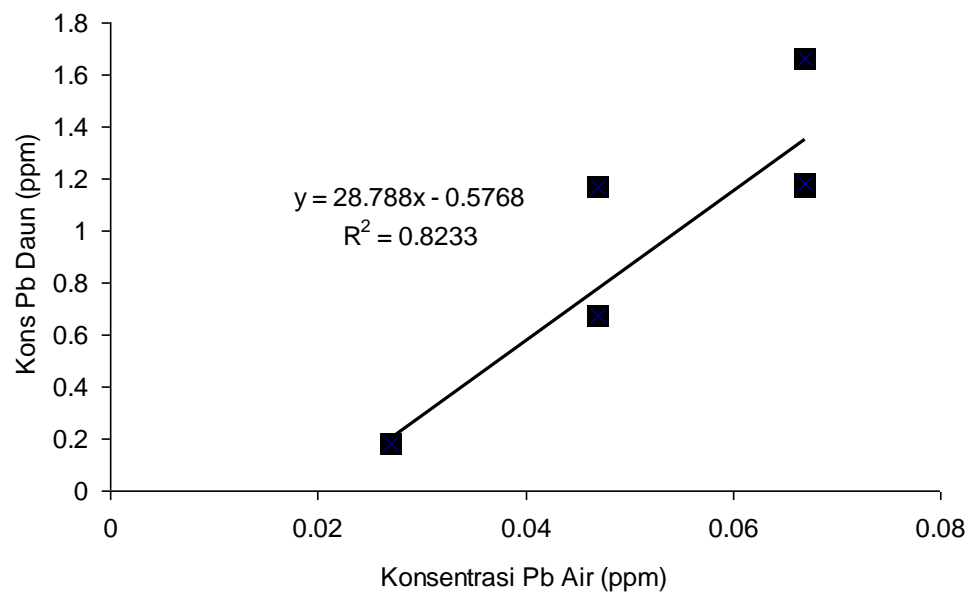

Gambar 3. Hubungan antara konsentarsi $\mathrm{Pb}(\mathrm{ppm})$ dalam air laut dan dalam daun lamun $T$. hemprichii di perairan Pulau Panjang Jepara

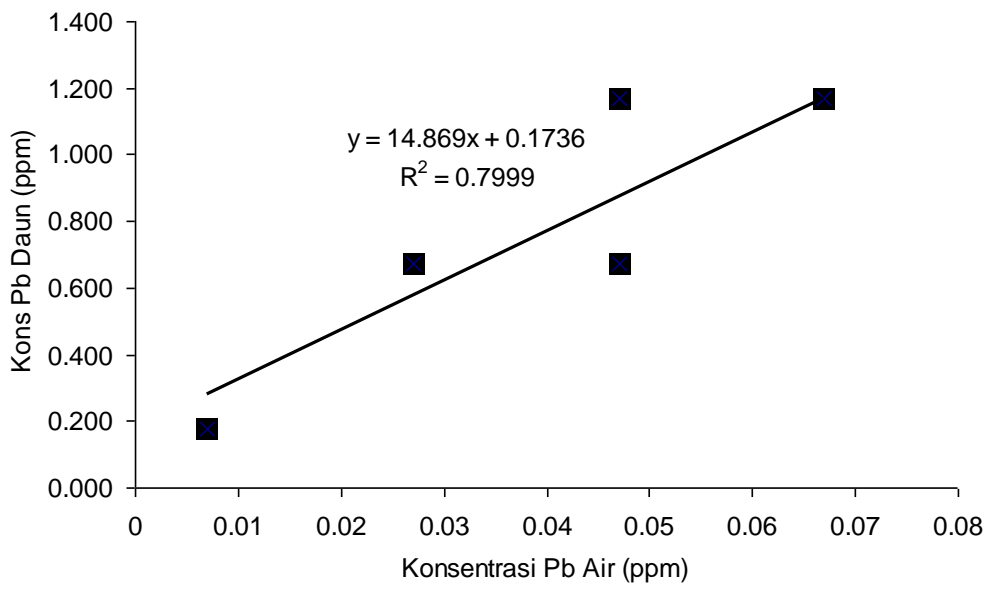

Gambar 4. Hubungan antara konsentarsi $\mathrm{Pb}(\mathrm{ppm})$ dalam air laut dan dalam daun segrass di perairan Bandengan Jepara 


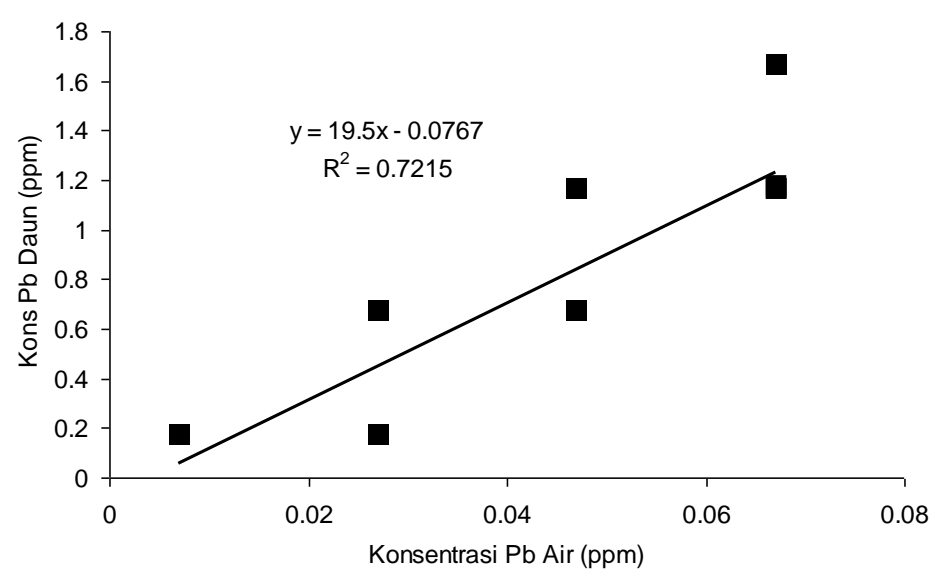

Gambar. 5 Hubungan antara konsentarsi $\mathrm{Pb}(\mathrm{ppm})$ dalam air laut dan dalam daun segrass di perairan P Panjang dan Bandengan Jepara

Hasil hubungan konsentrasi $\mathrm{Pb}$ dengan daun lamun di air dalam penelitian ini dapat menujukkan bahwa kandungan logam berat $\mathrm{Pb}$ pada daun lamun $T$. hemprichii di kedua perairan memiliki nilai sangat erat sehingga dapat dikatakan bahwa terjadi kontaminasi logam berat Timbal $(\mathrm{Pb})$ dalam air dan lamun yang akan berdampak langsung bagi kesehatan ekosistem dalam perairan. Kandungan logam yang terdapat pada daun lamun memiliki kebutuhan fisiologi dari vegetasi tersebut (Ismarti et al., 2017). Diperkuat juga oleh Kiswara (1992) menyatakan, tumbuhan lamun mempunyai kemampuan untuk melepaskan bahan yand tidak dibutukan ke perairan melalui daun. Sedangkan daun juga merupakan tempat penyerapan nutrisi dari kolom air, dengan menggunakan kultikula yang dapat menyerap nutrient langsung di perairan. Supriyantini et al. (2016), menyatakan penyerapan kandungan logam berat dipengaruhi oleh umur lamun $T$. hemprichii semakin tua tumbuhan lamun maka kemampuan daun dalam menyerap logam berat meningkat. Lingby \& Brix (1982), mengatakan umur daun lamun mempengaruhi jumlah kadar logam beratnya, sehingga kadar $\mathrm{Pb}$ meningkat sesuai dengan pertambahan umur.

Logam $\mathrm{Pb}$ dapat menyebabkan pengurangan kandungan klorofil dalam daun lamun. Konsentrasi $\mathrm{Pb}$ yang tinggi dapat merusak bagian kloroplas. Menurut Arunakumara \& Zhang (2009), kerusakan kloroplas dapat menyebabkan kerusakan pada pigmen fotosintesis yang kebanyakan disebabkan oleh toksisitas logam $\mathrm{Pb}$. Logam $\mathrm{Pb}$ juga dapat terikat sehingga aktivitas fotosintesis terganggu dan dan menghalangi pertumbuhan atau matinya sel-sel dalam jaringan terutama tumbuhan lamun itu sendiri (Kamaruddin et al., 2016). Peningkatan kadar logam berat pada air laut akan mengakibatkan logam berat yang semula dibutuhkan untuk berbagai proses metabolisme dapat berubah menjadi racun bagi organisme laut (Herfina et al., 2014).

\section{KESIMPULAN}

Hasil penelitian dapat disimpulkan bahwa konsentrasi $\mathrm{Pb}$ dalam air laut di kedua lokasi tersebut berkorelasi postip terhadap $\mathrm{Pb}$ dalam daun lamun T. hemprichii. Peningkatan konsentrasi $\mathrm{Pb}$ dalam air laut akan diikuti peningkatan $\mathrm{Pb}$ dalam daun lamun. Konsentrasi $\mathrm{Pb}$ dalam air laut antara 0,034 - 0,054 ppm sedangkan dalam daun lamun 0,509-1,334 ppmyang ada di kedua daerah sersebut rata rata antara $0,034-0,054 \mathrm{ppm}$.

\section{UCAPAN TERIMAKASIH}

Artikel ini merupakan bagian dari skripsi yang berjudul "Analisis Penyerapan Kandungan Logam Berat Pb (Timbal) pada Lamun (Thalassia hemprichii) di Perairan Pulau Panjang dan Pantai Bandengan Jepara" untuk memperoleh gelar Sarjana Strata Satu Program Studi IImu Kelautan, Fakultas Perikanan dan Ilmu Kelautan, Universitas Diponegoro. 


\section{DAFTAR PUSTAKA}

Arunakumara, K.K.I.U. \& Zhang, X. 2009. Efek Metals Heavy (Pb2 + lan Cd 2+) ing Ultrastuktur, Wutah lan pigmen saka Unicellular Cyanobacterium Synechocystis sp. Jurnal Oceanology ang Limnology, 27 (2): 383-388.

Hartati, R., Widianingsih, Adi, S., Hadi, E., Muhammad, Z., Riniatsih, I., Saputra, W.L., \& Mahendrajaya, R.T. 2017. Variasi Komposisi Dan Kerapatan Jenis Lamun Di Perairan Ujung Piring, Kabupaten Jepara. Jurnal Kelautan Tropis, 20(2):96-105

Herfina, Ruswahyuni, \& Sulardiono, B. 2014. Hubungan Kelimpahan Epifauna yang Berasosiasi dengan Lamun pada Tingkat Kerapatan Lamun yang Berbeda di Pantai Pulau Panjang, Jepara. Diponegoro Journal of Marquares, 3(1):193-201.

Indarjo, A. 2015. Kesesuaian Ekowisata Snorkling di Perairan Pulau Panjang Jepara Jawa Tengah. Jurnal Harpodon Borneo, 8(1):1-6

Ismarti, I., Ramses, R., Amelia, F., \& Suheryanto, S. 2017. Kandungan tembaga (Cu) dan timbal $(\mathrm{Pb})$ pada lamun Enhalus accoroides dari Perairan Batam, Riau Kepulauan, Indonesia. Depik, 6(1): 9-22.

Kamaruddin, S.Z, Sendy, B.R., \& Pience, V. 2016. Keragaman Lamun (Seagrass) di Pesisir Desa Lihunu Pulau Bangka Kecamatan Likupang Kabupaten Minahasa Utara, Sulawesi Utara. Jurnal Mipa Unsrat Online, 5(1) 20-24.

Kiswara, W. 1992. Vegetasi Lamun (Seagrass) di Rataan Terumbu Pulau Pari, Pulau-pulau Seribu. Jurnal Oseonologi Indonesia, 2(5):31-49

KMNLH (Keputusan Menteri Negara LingkunganHidup). 2004. No.Kep51/2004 tentang Pedoman Penetapan Baku Mutu Air Laut, Kantor Menteri Negara Lingkugan Hidup, Jakarta.

Lingby, J.E., \& Brix, G., 1982. Uptake and Translocation of Phosporus in Eelgrass (Zostera marina). Marine Biology, 90(1):111-116

Nursanti, Riniatsih, I. \& Satriadi, A. 2013. Studi Hubungan Kerapatan Vegetasi Lamun dengan Laju Sedimentasi di Perairan Teluk Awur dan Bandengan Jepara Pada Periode Juni-Juli 2012. Journal of Marine Research, 2(3):25-34.

Purwanti, F., Aurora, M., \& Agung, S. 2014. Analisis Hubungan Keberadaan dan Kelimpahan Lamun dengan Kualitas Air di Pulau Karimun Jawa, Jepara. Diponegoro Journal of Maquares, 3(3):88-94

Putra, B.A., Santoso, A., \& Riniatsih, I. 2019. Kandungan Logam Berat Seng pada Enhalus acoroides di Perairan Jepara. Buletin Oseanografi Marina, 8(1):9-16

Rappe, R.D., Lajus, M.J. \& Schreider., 2011. Heavy metal impact on growth and leaf asymmetry of seagrass, Halophila ovalis. Journal of Environmental Chemistry and Ecotoxicology, 3(6):149159

Riniatsih, I., Widianingsih, W., Redjeki, S., \& Endrawati, H. 2013. Kelimpahan Fitoplankton di Padang Lamun Buatan. Jurnal IImu Kelautan, 18(2):84-90

Riza, F., Bambang, A.N, \& Kismartini. 2015. Tingkat Pencemaran Lingkungan Perairan Ditinjau dari Aspek Fisika, Kimia, dan Logam di Pantai Kartini Jepara. Indonesian Journal of Conservation, 4(1):52-60

Sari, S.P., Dwi, R., \& Wahyu, A., 2017. Bioakumulasitimbal (Pb) dan cadmium (Cd) pada lamun Cymodocea serrulata di Perairan Bangka Selatan. Jurnal IImu-IImu Perairan, Pesisir dan Perikanan. 6(2):128-137

Sugiyanto, Y. S., \& Ruswahyuni., 2016. Hubungan Antara Kelimpahan Epifauna Dasar Dengan Tingkat Kerapatan Lamun Yang Berbeda di Pulau Panjang dan Teluk Awur Jepara. Journal of Maquares. 3(4):235-242.

Sulardiono, B.H., \& Rudiyanti., A.,S. 2016. Hubungan Logam Berat Tibal (Pb) dan Kadmium (Cd) Terlarut dengan Kelimpahan Fitoplankton di Sungai Silandak Semarang. Diponegoro Journal of Maquares. 5(4):388-394

Supriyantini, E., Sedjati, S., \& Nurfadhli, Z., 2016. Akumulasi LogamBerat Zn (seng) pada Lamun Enhalus acoroides dan Thalassia hemprichii di Perairan Pantai Kartini Jepara. Buletin Oseanografi Marina, 5(1):14-20 